\title{
PENDAMPINGAN IBU HAMIL DI DESA FOKUS STUNTING KABUPATEN LAMPUNG TIMUR
}

\author{
Counseling for pregnant women in the focus stunting village of \\ Lampung Timur District \\ Bertalina ${ }^{1}$, Antun Rahmadi ${ }^{1}$ \\ 1Jurusan Gizi Poltekkes Kemenkes Tanjungkarang, Jl. Hajimena No 100 Kecamatan Natar, \\ Kabupaten Lampung Selatan, Lampung \\ E-mail: bertalina@poltekkes-tjk.ac.id
}

\begin{abstract}
Stunting is a condition of failure to thrive in children under five as a result of chronic malnutrition so that the child is too short for his age. Stunting can occur in the womb due to inadequate nutritional intake during pregnancy. This study aims to examine the effect of mentoring on the knowledge and behavior of pregnant women in focus-stunting villages. The intervention is nutritional counseling using standard operating procedures and booklets. Mentoring is carried out by nutritionist one times a week for one month. The study is a quasi-experiment with a non-randomized control group design pre-test - post-test design. The subjects were 60 people who were selected purposively from the population of pregnant women in 6 villages in East Lampung Regency. Data analysis used Wilcoxon Rank Test and Mann Whitney. The results showed that there were significant differences in knowledge energy and protein intake. No difference in consumption of sulfas ferosus supplements between the two groups. Nutritional assistance for pregnant women increases knowledge and nutritional intake. A nutritionist can take the mother's class to strengthen nutrition assistance to pregnant women. Assistance to breastfeeding mothers can be used as a topic in further research.
\end{abstract}

Keywords: stunting, counseling pregnant women, knowledge, consumption of energy and protein

\section{ABSTRAK}

Stunting adalah kondisi gagal tumbuh pada anak balita akibat dari kekurangan gizi kronis sehingga anak terlalu pendek untuk usianya. Stunting dapat terjadi sejak dalam kandungan yang disebabkan karena asupan gizi yang tidak memadai selama kehamilan. Penelitian bertujuan untuk mengkaji pengaruh pendampingan terhadap pengetahuan dan perilaku ibu hamil di desa fokus stunting. Bentuk intervensi pendampingan adalah konseling gizi menggunakan standar operasional prosedur dan booklet. Pendampingan dilakukan oleh nutrisionis selama satu bulan dengan frekuensi satu kali seminggu. Jenis penelitian ini adalah quasi experiment dengan rancangan non randomized control group pre test - post test design. Subjek penelitian berjumlah 60 orang yang dipilih secara purposiv dari populasi ibu hamil di 6 desa di Kabupaten Lampung Timur. Analisis data menggunakan Wilcoxon Rank Test dan Mann Whitney. Hasil penelitian menunjukkan ada perbedaan signifikan pengetahuan, asupan energi dan protein. Tidak ada perbedaan konsumsi suplemen tablet tambah darah (TTD) antara kelompok perlakuan dan kelompok kontrol. Pendampingan nutrisionis kepada ibu hamil meningkatkan pengetahuan dan asupan gizi. Nutrisionis agar memanfaatkan kelas ibu untuk memperkuat pendampingan gizi kepada ibu hamil. Pendampingan kepada ibu menyusui dapat dijadikan topik dalam penelitian lanjutan.

Kata kunci: stunting, pendampingan ibu hamil, pengetahuan, asupan energi dan protein 


\section{PENDAHULUAN}

$\mathrm{G}$ izi yang memadai merupakan landasan utama kesehatan setiap individu khususnya bagi seorang wanita. Anakanak dari wanita yang kurang gizi akan lebih berisiko menghadapi gangguan kognitif, stunting, resistensi yang lebih rendah terhadap infeksi, risiko penyakit dan kematian yang lebih tinggi sepanjang hidup mereka. De Onis (2016) menyebutkan bahwa stunting pada anak adalah dampak dari kekurangan gizi ibu dan pemberian makan bayi dan anak yang tidak memadai. ${ }^{1}$ Status gizi wanita sebelum, selama, dan setelah kehamilan, termasuk penambahan berat badan yang tidak memadai selama kehamilan, mempengaruhi hasil kelahiran dan persalinan. Hambatan pertumbuhan janin menyebabkan bayi yang dilahirkan terlalu kecil, yang memiliki konsekuensi sepanjang hidup. ${ }^{2}$ Bukti ilmiah yang dipresentasikan pada seminar yang diselenggarakan oleh UNICEF-WHO menekankan kembali pentingnya jendela 1000 hari pertama kehidupan (1000 HPK) waktu dimana fondasi diletakkan untuk menentukan pencapaian ukuran fisik, kapasitas fisiologis dan intelektual seseorang di kemudian hari. ${ }^{3}$

Indonesia masih menghadapi berbagai masalah gizi pada periode $1000 \mathrm{HPK}$. Masalah pada ibu hamil seperti Kurang Energi Kronik (KEK) dan anemia prevalensinya masih cukup tinggi. Hasil survei Riskesdas tahun 2018 menunjukkan bahwa prevalensi KEK pada ibu hamil di Indonesia sebesar 17,3 persen sedangkan prevalensi anemia mencapai 23,7 persen. Status gizi ibu yang diukur dengan Indeks Massa Tubuh (IMT) juga masih menunjukkan masalah misalnya IMT pada wanita dewasa yang berkategori kurus sebesar 7,8 persen. Tinggi badan ibu hamil yang termasuk berisiko $(<150 \mathrm{~cm})$ angkanya juga cukup besar yaitu 30,5 persen. Demikian pula capaian indikator kinerja kesehatan ibu, angkanya masih belum menggembirakan. Tercatat diantaranya adalah distribusi vitamin $\mathrm{A}$ pada ibu nifas baru mencapai 57,2 persen, pemberian tablet tambah darah (TTD) dan Pemberian Makanan Tambahan (PMT) bagi ibu hamil baru sebesar 51 persen dan 25,2 persen. Selain itu masih terdapat 41,8 persen ibu menyusui yang belum melakukan inisiasi menyusu dini (IMD). Kondisi pada wanita seperti di atas berdampak pada masalah gizi pada anak. Tercatat ada sebesar 6,2 persen berat badan lahir rendah (BBLR) dan 4 persen BBLR dengan panjang badan lahir rendah. Pada anak 0-59 bulan terdapat 3,9 persen gizi buruk, 11,5 persen sangat pendek dan 3,5 persen sangat kurus. ${ }^{4}$ Berbagai upaya sensitif dan spesifik telah dilakukan untuk perbaikan gizi ibu hamil, bayi dan balita namun kenyataannya masih banyak keluarga yang mempunyai perilaku gizi yang tidak sehat. Masih banyaknya permasalahan status gizi ibu hamil, bayi dan balita menunjukkan bahwa asuhan gizi tingkat keluarga belum memadai. Mengatasi masalah gizi pada wanita memiliki sejumlah efek positif karena wanita yang sehat dapat memenuhi berbagai peran mereka seperti memastikan gizi keluarga mereka dan memiliki anak yang sehat.

Pada umumnya wanita yang memiliki kendali lebih besar atas sumber daya rumah tangga cenderung lebih sehat dan lebih baik status gizi keluarganya karena akan cenderung menghabiskan lebih banyak sumber daya untuk nutrisi, kesehatan, dan kesejahteraan rumah tangga mereka. Karena alasan itu maka program untuk meningkatkan gizi harus fokus pada peningkatan pengetahuan wanita tentang gizi dan pemberdayaan wanita dalam pengambilan keputusan.

Masalah malnutrisi jarang yang sederhana, karena itu program penanggulangannya perlu dirancang untuk mengatasi berbagai faktor yang menentukan masalah gizi pada populasi target dan melibatkan masyarakat. Partisipasi masyarakat merupakan keterlibatan sukarela oleh masyarakat dalam perubahan yang ditentukan sendiri. Partisipasi masyarakat dapat juga diartikan keterlibatan masyarakat dalam pembangunan diri, kehidupan dan lingkungan mereka. ${ }^{5}$ Salah satu upaya untuk melakukan perubahan perilaku masyarakat, mengubah gaya hidup dan kualitas hidup yang lebih baik dengan melibatkan masyarakat adalah melalui pendampingan oleh petugas kesehatan yang kompeten. Tujuannya adalah untuk meningkatkan kapasitas dan kapabilitas masyarakat agar mampu mengenali permasalahan yang dihadapi, mampu menggali dan memanfaatkan sumber daya yang tersedia, serta mampu mengeksistensikan diri secara jelas. ${ }^{6}$

Program terkait intervensi dengan sasaran ibu hamil dilakukan untuk mengurangi serta menangani pervalensi stunting diantaranya 
adalah 1) pemberian makanan tambahan pada ibu hamil untuk mengatasi kekurangan energi dan protein kronis, 2) program untuk mengatasi kekurangan zat besi dan asam folat, 3) program untuk mengatasi kekurangan iodium, 4) pemberian obat cacing untuk menanggulangi kecacingan pada ibu hamil, 5) program untuk melindungi ibu hamil dari malaria. ${ }^{7}$ Untuk mendukung agar kegiatan intervensi berjalan dengan efektif diperlukan upaya peningkatan kapasitas khususnya kepada ibu hamil agar mampu memanfaatkan program yang dijalankan pemerintah. Pendampingan kepada ibu hamil dalam upaya perubahan perilaku sehat merupakan upaya strategis yang dapat dilaksanakan guna mencapai target program yaitu percepatan penurunan stunting. Tujuan penelitian adalah diketahuinya pengaruh pendampingan terhadap perilaku dan pengetahuan ibu hamil di desa fokus stunting Kabupaten Lampung Timur.

\section{METODE PENELITIAN}

Jenis penelitian ini termasuk penelitian eksperimental menggunakan pendekatan quasi experiment dengan rancangan penelitian non randomized control group pretest - posttest design. Pada penelitian ini subjek penelitian dibagi kedalam kelompok perlakuan dan kelompok kontrol. Pada kedua kelompok dilakukan penilaian pengetahuan, konsumsi pangan, dan konsumsi suplemen TTD di awal dan akhir penelitian. Pada kelompok perlakuan dilakukan intervensi pendampingan berupa konseling gizi menggunakan SOP dan booklet oleh nutrisionis seminggu sekali selama dua bulan sedangkan kelompok kontrol hanya diberikan booklet. Pendampingan melibatkan empat orang nutrisionis dari empat Puskesmas setempat.

Populasi dalam penelitian ini adalah seluruh ibu hamil di enam desa fokus stunting di Kabupaten Lampung Timur. Perhitungan besar sampel menggunakan rumus Lemeshow diperoleh sampel sebanyak 60 ibu hamil. ${ }^{8}$ Pemilihan sampel penelitian dilakukan secara purposive dengan kriteria bersedia secara sukarela menjadi subjek penelitian.

Variabel independen dalam penelitian ini adalah pendampingan ibu hamil oleh nutrisionis sedangkan variabel dependen adalah pengetahuan dan perilaku ibu hamil. Variabel pengetahuan meliputi pengetahuan tentang makanan bayilanak, kesehatan ibu anak, dan pola asuh anak. Variabel perilaku meliputi perilaku konsumsi pangan dan konsumsi suplemen TTD.

Data karakteristik subjek penelitian dikumpulkan melalui wawancara dengan instrumen kuesioner dan pengukuran lingkar lengan atas (LiLA) dengan pita LiLA untuk mengetahui risiko KEK dengan ambang batas $23,5 \mathrm{~cm}$. Pretest dan posttest pengetahuan subjek penelitian dikumpulkan dengan metode wawancara menggunakan instrumen kuesioner pengukuran tingkat pengetahuan yang telah divalidasi. Data awal dan akhir konsumsi pangan dikumpulkan dengan metode wawancara menggunakan formulir 24-h food recall. Data awal asupan suplemen TTD dikumpulkan dengan wawancara sedangkan data akhir dikumpulkan dengan metode self report menggunakan formulir pencatatan konsumsi TTD selama sebulan terakhir.

Analisis data karakteristik subjek penelitian dilakukan untuk mendeskripsikan karakteristik subjek penelitian dari kedua kelompok melalui ukuran statistik pemusatan data dan variasi data (mean dan standar deviasi). Karakteristik subjek penelitian yang dianalisis meliputi umur ibu saat ini, umur saat menikah, umur saat pertama kali hamil, urutan kehamilan, umur kehamilan saat ini, jumlah anak kandung, jarak kelahiran, pendidikan ibu, pekerjaan ibu, pekerjaan suami, pendapatan keluarga, dan risiko KEK. Untuk mengetahui kesetaraan karakteristik antara kelompok perlakuan dan kelompok kontrol pada awal penelitian dianalisis menggunakan uji statistik Independent samples T-test dan Chi-square test. Data karakteristik subjek penelitian yang berskala interval diuji dengan Independent samples T-test sedangkan data dengan skala kategori diuji dengan Chisquare test. Untuk mengetahui signifikasi perbedaan pengetahuan, perilaku konsumsi pangan dan konsumsi TTD antara sebelum dan sesudah intervensi pada masing-masing kelompok dilakukan uji statistik Wilcoxon Rank Test, sedangkan uji statistik Mann Whitney digunakan untuk mengetahui perbedaan pengetahuan, perilaku konsumsi pangan dan konsumdi TTD antara kelompok perlakuan dan kelompok kontrol baik sebelum dan sesudah intervensi. 
Tabel 1

Karakteristik Subjek Penelitian

\begin{tabular}{|c|c|c|c|}
\hline \multirow[b]{2}{*}{ Variabel } & \multicolumn{2}{|c|}{ Kelompok } & \multirow[b]{2}{*}{$p$-value } \\
\hline & $\begin{array}{c}\text { Perlakuan } \\
n=30\end{array}$ & $\begin{array}{c}\text { Kontrol } \\
n=30\end{array}$ & \\
\hline \multicolumn{4}{|c|}{ Umur ibu saat ini: } \\
\hline - Mean & 27,5 & 30,1 & \multirow{2}{*}{$0,151^{*}$} \\
\hline$-S D$ & 6,52 & 7,14 & \\
\hline \multicolumn{4}{|c|}{ Umur saat menikah: } \\
\hline - Mean & 20,9 & 20,8 & \multirow[t]{2}{*}{$0,945^{\star}$} \\
\hline$-S D$ & 3,80 & 3,58 & \\
\hline \multicolumn{4}{|c|}{ Umur saat pertama kali hamil: } \\
\hline - Mean & 21,6 & 21,7 & \multirow[t]{2}{*}{$0,883^{*}$} \\
\hline - SD & 3,9 & 3,1 & \\
\hline \multicolumn{4}{|l|}{ Kehamilan ke-: } \\
\hline - Mean & 2,0 & 2,4 & \multirow[t]{2}{*}{$0,277^{*}$} \\
\hline$-S D$ & 1,1 & 1,5 & \\
\hline \multicolumn{4}{|c|}{ Umur kehamilan saat ini: } \\
\hline - Mean & 4,5 & 5,0 & \multirow[t]{2}{*}{$0,249^{*}$} \\
\hline \multicolumn{3}{|c|}{ Jumlah anak kandung: } & \\
\hline - Mean & 0,9 & 1,2 & \multirow[t]{3}{*}{$0,426^{*}$} \\
\hline$-S D$ & 1,0 & 1,4 & \\
\hline \multicolumn{3}{|l|}{ Jarak kelahiran: } & \\
\hline - Mean & 3,4 & 4,9 & \multirow[t]{2}{*}{$0,191^{*}$} \\
\hline$-S D$ & 3,7 & 5,1 & \\
\hline \multicolumn{4}{|l|}{ Pendidikan ibu: } \\
\hline$-S D$ & 2 & 7 & \multirow{4}{*}{$0,271^{* *}$} \\
\hline - SMP & 14 & 14 & \\
\hline - SMA & 12 & 8 & \\
\hline - PT & 2 & 1 & \\
\hline \multicolumn{4}{|l|}{ Pekerjaan ibu: } \\
\hline - Bekerja & 2 & 5 & \multirow{2}{*}{$0,384^{* *}$} \\
\hline - Tidak bekerja & 28 & 25 & \\
\hline \multicolumn{4}{|c|}{ Pekerjaan suami: } \\
\hline - Petani & 15 & 14 & \multirow{4}{*}{$0,992^{* *}$} \\
\hline - Buruh & 7 & 8 & \\
\hline - Wiraswasta & 7 & 7 & \\
\hline - Sopir & 1 & 1 & \\
\hline \multicolumn{4}{|c|}{ Pendapatan keluarga: } \\
\hline - Mean & 1.260 .000 & 1.710 .000 & \multirow[t]{2}{*}{$0,116^{*}$} \\
\hline - SD & 790.100 & 1.340 .000 & \\
\hline \multicolumn{4}{|l|}{ Risiko KEK: } \\
\hline$-Y a$ & 26 & 25 & $1,000^{* *}$ \\
\hline - Tidak & 4 & 5 & \\
\hline
\end{tabular}


HASIL

\section{Karakteristik}

Hasil uji statistik terhadap data karakteristik subjek penelitian yang berkaitan dengan umur seperti umur saat ini, umur saat menikah, dan umur saat pertama kali hamil menunjukkan tidak ada perbedan antara kelompok perlakuaan dan kelompok kontrol ( $p$ value $=0,151-0,945)$. Karakteristik subjek penelitian yang berkaitan dengan kehamilan dan kelahiran seperti urutan kehamilan saat ini, umur kehamilan saat ini, jumlah anak kandung dan jarak kelahiran menunjukkan tidak ada perbedan antara kelompok perlakuaan dan kelompok kontrol (p-value $=0,191-0,426)$. Karakteristik sosial ekonomi subjek penelitian seperti tingkat pendidikan, pekerjaan dan pendapatan juga menunjukkan tidak ada perbedan antara kelompok perlakuaan dan kelompok kontrol. ( $p$-value $=0,116-0,992)$. Demikian juga dengan karakteristik subjek penelitian yang berkaitan dengan status gizi saat ini yang diukur dengan LiLA menunjukkan tidak ada perbedan antara kelompok perlakuaan dan kelompok kontrol. ( $p$-value $=1,000)$. Hasil uji statistik tentang perbedaan karakteristik subjek penelitian antara kelompok perlakuan dan kelompok kontrol selengkapnya dapat dilihat pada Tabel 1.

Tabel 2

Perbedaan Skor Pengetahuan tentang Makanan Bayi/Anak, Kesehatan Ibu dan anak, Pola asuh, Asupan Energi, Asupan Protein, dan Konsumsi Tablet Tambah Darah pada Kelompok Perlakuan dan Kontrol di Desa Fokus Stunting Kabupaten Lampung Timur

\begin{tabular}{|c|c|c|c|c|c|}
\hline \multirow{2}{*}{ Kelompok } & \multicolumn{2}{|c|}{ Sebelum Pendampingan } & \multicolumn{2}{|c|}{ Sesudah Pendampingan } & \multirow{2}{*}{$p$ value* } \\
\hline & $\overline{\mathrm{X}} \pm \mathrm{SD}$ & $95 \% \mathrm{Cl}$ & $\overline{\mathrm{X}} \pm \mathrm{SD}$ & $95 \% \mathrm{Cl}$ & \\
\hline \multicolumn{6}{|c|}{ Pengetahuan Makanan Bayi/anak } \\
\hline - Perlakuan & $31,1 \pm 8,5$ & $15,8-52,6$ & $41,4 \pm 8,6$ & $26,0-58,0$ & 0,000 \\
\hline - Kontrol & $30,8 \pm 10,8$ & $5,3-47,4$ & $34,2 \pm 12,0$ & $5,0-53,0$ & 0,096 \\
\hline - $p$ value ${ }^{* *}$ & \multicolumn{2}{|c|}{0,696} & \multicolumn{2}{|c|}{0,000} & \\
\hline \multicolumn{6}{|c|}{ Pengetahuan tentang Kesehatan Ibu dan Anak (KIA } \\
\hline - Perlakuan & $53,6 \pm 14,8$ & $27,0-91,0$ & $71,5 \pm 14,9$ & $46,0-100,0$ & 0,000 \\
\hline - Kontrol & $53,3 \pm 18,7$ & $15,8-52,6$ & $59,1 \pm 20,8$ & $9,0-82,0$ & 0,094 \\
\hline - $p$ value ${ }^{* *}$ & \multicolumn{2}{|c|}{0,811} & \multicolumn{2}{|c|}{0,017} & \\
\hline \multicolumn{6}{|c|}{ Pengetahuan tentang Pola Asuh Anak } \\
\hline - Perlakuan & $49,0 \pm 16,1$ & $20,0-90,0$ & $63,3 \pm 20,2$ & $30,0-100,0$ & 0,000 \\
\hline - Kontrol & $52,0 \pm 14,5$ & $11,4-83,6$ & $54,3 \pm 16,1$ & $20,4-79,1$ & 0,257 \\
\hline - $p$ value ${ }^{* *}$ & \multicolumn{2}{|c|}{0,619} & \multicolumn{2}{|c|}{0,013} & \\
\hline \multicolumn{6}{|l|}{ Asupan Energi } \\
\hline - Perlakuan & $1272,7 \pm 479,4$ & $603,7-2297,0$ & $1750,7 \pm 438,3$ & $1076,7-2614,6$ & 0,000 \\
\hline - Kontrol & $1270,1 \pm 478,3$ & $636,8-2280,7$ & $1434,4 \pm 463,5$ & $661,6-2454,4$ & 0,101 \\
\hline$-p$ value** & \multicolumn{2}{|c|}{0,882} & \multicolumn{2}{|c|}{0,008} & \\
\hline \multicolumn{6}{|l|}{ Asupan Protein } \\
\hline - Perlakuan & $35,5 \pm 13,0$ & $11,4-58,6$ & $54,8 \pm 12,9$ & $32,4-79,1$ & 0,000 \\
\hline - Kontrol & $41,1 \pm 12,6$ & $22,5-62,7$ & $45,1 \pm 15,2$ & $12,0-71,9$ & 0,103 \\
\hline$-p$ value** & \multicolumn{2}{|c|}{0,119} & \multicolumn{2}{|c|}{0,036} & \\
\hline \multicolumn{6}{|c|}{ Konsumsi Suplemen tambah darah } \\
\hline - Perlakuan & $14,4 \pm 11,2$ & $0-30$ & $22,1 \pm 8,4$ & $5-30$ & 0,000 \\
\hline - Kontrol & $17,1 \pm 10,5$ & $0-30$ & $22,4 \pm 7,6$ & $8-30$ & 0,000 \\
\hline$-p$ value** & \multicolumn{2}{|c|}{0,317} & \multicolumn{2}{|c|}{0,866} & \\
\hline
\end{tabular}




\section{Pengetahuan}

Rata-rata skor pengetahuan subjek penelitian tentang makanan bayi/anak sebelum pendampingan masing-masing adalah $31,1 \pm 8,5$ pada kelompok perlakuan dan $30,8 \pm 10,8$ pada kelompok kontrol. Berdasarkan uji statistik skor tersebut tidak berbeda secara signifikan ( $p$-value 0,696). Setelah pendampingan skor pengetahuan tentang makanan bayilanak masing-masing menjadi $41,4 \pm 8,6$ pada kelompok perlakuan dan $34,2 \pm 12,0$ pada kelompok kontrol atau meningkat sebesar 33 persen dan 11 persen dan secara statistik ada perbedaan yang signifikan ( $p$-value 0,000). Terdapat peningkatan skor pengetahuan tentang makanan bayilanak pada kelompok perlakuan sebelum dan sesudah pendampingan sebesar 33 persen. Peningkatan tersebut signifikan secara statistik dengan p-value 0,000 sedangkan pada kelompok kontrol tidak berbeda secara signifikan ( $p$-value 0,096). Rincian hasil uji beda skor pengetahuan tentang makanan bayilanak tersaji dalam Tabel 2.

Rata-rata skor pengetahuan subjek penelitian tentang KIA sebelum pendampingan masing-masing adalah 53,6 $\pm 14,8$ pada kelompok perlakuan dan $53,3 \pm 18,7$ pada kelompok kontrol. Berdasarkan uji statistik skor tersebut tidak berbeda secara signifikan ( $p$ value 0,811). Setelah pendampingan skor pengetahuan subjek penelitian tentang KIA masing-masing menjadi $71,5 \pm 14,9$ pada kelompok perlakuan dan $59,1 \pm 20,8$ pada kelompok kontrol dan secara statistik ada perbedaan yang signifikan ( $p$-value 0,017). Terdapat peningkatan skor pengetahuan tentang KIA pada kelompok perlakuan sebelum dan sesudah pendampingan sebesar 34 persen. Peningkatan tersebut signifikan secara statistik dengan $p$-value 0,000 sedangkan pada kelompok kontrol tidak berbeda secara signifikan ( $p$-value 0,094$)$. Rincian hasil uji beda skor pengetahuan tentang KIA tersaji dalam Tabel 2.

Rata-rata skor pengetahuan subjek penelitian tentang pola asuh anak sebelum pendampingan masing-masing adalah $49,0 \pm 16,1$ pada kelompok perlakuan dan $52,0 \pm 14,5$ pada kelompok kontrol. Berdasarkan uji statistik skor tersebut tidak berbeda secara signifikan ( $p$-value 0,619). Sesudah pendampingan skor pengetahuan subjek penelitian tentang pola asuh anak masingmasing menjadi $63,3 \pm 20,2$ pada kelompok perlakuan dan $54,3 \pm 16,1$ pada kelompok kontrol dan secara statistik ada perbedaan yang signifikan ( $p$-value 0,013). Terdapat peningkatan skor pengetahuan tentang pola asuh anak pada kelompok perlakuan sebelum dan sesudah pendampingan sebesar 29 persen. Peningkatan tersebut signifikan secara statistik dengan $p$-value 0,000 sedangkan pada kelompok kontrol tidak berbeda secara signifikan ( $p$-value 0,257 ). Rincian hasil uji beda skor pengetahuan tentang makanan bayilanak tersaji dalam Tabel 2.

\section{Perilaku}

Pada Tabel 2 terlihat bahwa rata-rata asupan energi subjek penelitian sebelum pendampingan masing-masing adalah $1272,7 \pm 479,4$ kkal pada kelompok perlakuan dan $1270,1 \pm 478,3$ kkal pada kelompok kontrol. Berdasarkan uji statistik asupan tersebut tidak berbeda secara signifikan ( $p$-value 0,882). Sesudah pendampingan asupan energi subjek penelitian masing-masing menjadi $1750,7 \pm 438,3$ kkal pada kelompok perlakuan dan $1434,4 \pm 463,5$ kkal pada kelompok kontrol dan secara statistik ada perbedaan yang signifikan ( $p$-value 0,008). Pada kelompok perlakuan terdapat peningkatan asupan energi rata-rata sebesar $478 \mathrm{kkal}$ (38\%) antara sebelum dan sesudah pendampingan. Perbedaan tersebut signifikan secara statistik dengan $p$-value 0,000 sedangkan pada kelompok kontrol tidak berbeda secara signifikan ( $p$-value 0,101 ).

Pada Tabel 2 disajikan hasil uji statistik asupan protein subjek penelitian sebelum dan sesudah pendampingan. Rata-rata asupan protein subjek penelitian sebelum pendampingan masing-masing adalah 35,5 \pm 13,0 gram pada kelompok perlakuan dan $41,1 \pm 12,6$ gram pada kelompok kontrol. Berdasarkan uji statistik asupan tersebut tidak berbeda secara signifikan ( $p$-value 0,119). Sesudah pendampingan asupan protein subjek penelitian masing-masing menjadi $54,8 \pm 12,9$ gram pada kelompok perlakuan dan $45,1 \pm 15,2$ gram pada kelompok kontrol dan secara 
statistik ada perbedaan yang signifikan ( $p$-value 0,036 ). Pada kelompok perlakuan terdapat peningkatan asupan protein rata-rata sebesar 19,3 gram (54\%) antara sebelum dan sesudah pendampingan. Perbedaan tersebut signifikan secara statistik dengan p-value 0,000 sedangkan pada kelompok kontrol tidak berbeda secara signifikan ( $p$-value 0,103$)$.

Rata-rata konsumsi suplemen TTD subjek penelitian dalam sebulan terakhir sebelum pendampingan masing-masing adalah $14,4 \pm 11,2$ tablet pada kelompok perlakuan $17,1 \pm 10,5$ tablet pada kelompok kontrol. Berdasarkan uji statistik konsumsi suplemen tersebut tidak berbeda secara signifikan ( $p$ value 0,317 ). Sesudah pendampingan konsumsi suplemen TTD subjek penelitian masing-masing menjadi 22,1 $\pm 8,4$ tablet pada kelompok perlakuan dan 22,4 \pm 7,6 tablet pada kelompok kontrol dan secara statistik tidak ada perbedaan yang signifikan ( $p$-value 0,886 ). Pada kedua kelompok terjadi peningkatan konsumsi suplemen TTD rata-rata sebanyak 7,7 tablet $(53 \%)$ pada kelompok perlakuan dan 5,3 (31\%) pada kelompok kontrol. Terdapat perbedaan signifikan asupan protein pada kelompok perlakuan dan kelompok kontrol dengan $p$-value 0,000 antara sebelum dan sesudah pendampingan. Rincian hasil uji beda konsumsi suplemen TTD tersaji dalam Tabel 2.

\section{BAHASAN}

\section{Pengetahuan}

Secara keseluruhan skor pengetahuan subjek penelitian mengalami peningkatan akan tetapi pada kelompok perlakuan meningkat secara signifikan dan tidak pada kelompok kontrol. Hasil penelitian ini sejalan dengan penelitian Putri (2019) yang menyatakan adanya pengaruh yang signifikan pemberian konseling gizi terhadap peningkatan pengetahuan ibu hamil sebelum dan sesudah perlakuan. ${ }^{9}$ Hasil penelitian ini juga serupa dengan penelitian Puspitasari (2019) bahwa konseling gizi seimbang dengan buku saku memberikan pengaruh signifikan terhadap pengetahuan ibu. ${ }^{10}$ Selanjutnya hasil penelitian Diddana et.al (2018) menyimpulkan bahwa pemberian pendidikan gizi berdasarkan Health Belief Model meningkatkan pengetahuan gizi dan praktik diet wanita hamil. ${ }^{11}$ Selanjutnya Zelalem et.al (2017) menyebutkan bahwa pendidikan gizi selama kehamilan oleh penyedia layanan kesehatan bisa meningkatkan pengetahuan dan praktek wanita selama hamil. 12

Pada penelitian ini intervensi pendampingan berhasil meningkatkan pengetahuan subjek penelitian pada kelompok perlakuan rata-rata sebesar 32 persen. Peningkatan pengetahuan subjek penelitian pada penelitian ini lebih tinggi jika dibandingkan dengan beberapa penelitian sejenis. Hasil penelitian Daranga (2020) menyebutkan bahwa konseling gizi intensif dengan menggunakan media leaflet efektif dalam meningkatkan pengetahuan ibu hamil sebesar 28,42 persen..$^{13}$ Hasil penelitian Yurni dan Sinaga (2017) menunjukkan bahwa terjadi peningkatan pengetahuan sebesar 5,9 persen setelah pemberian intervensi pendidikan gizi seimbang selama 2 minggu sebanyak 2 kali pertemuan. ${ }^{14}$ Selain itu penelitian Gamelia, E. dkk. (2015) juga menunjukkan bahwa pemberian konseling satu kali meningkatkan pengetahuan kesehatan responden sebesar 11,43 persen. ${ }^{15}$ Peningkatan skor pengetahuan gizi secara signifikan juga terjadi pada penelitian yang dilakukan oleh Hestuningtyas (2013) yaitu sebesar 18,2 persen pada kelompok ibu yang mendapat konseling gizi. ${ }^{16}$

Meningkatnya pengetahuan dapat terjadi karena subjek pada penelitian ini mendapat pendampingan berupa konseling gizi yang merupakan kegiatan komunikasi dua arah untuk menanamkan dan meningkatkan pengetahuan sebagai tahap awal dalam proses perubahan perilaku. ${ }^{17}$ Tidak demikian halnya dengan kelompok kontrol yang hanya mendapatkan informasi gizi dari booklet yang dibagikan.

Menurut Ambarwati, dkk. (2013), konseling menumbuhkan kerjasama dan komunikasi yang baik antar konselor sehingga menciptakan suasana yang nyaman. ${ }^{18} \mathrm{Hal}$ tersebut membuat konselor dapat menggali sejauh mana pengetahuan konsele kemudian mengembangkan pengetahuan tersebut menjadi lebih baik. Peningkatan pengetahuan juga dapat terjadi karena ada faktor pengulangan informasi yang diberikan pada saat konseling. Informasi yang diberikan secara berulang-ulang meningkatkan pengetahuan seseorang. ${ }^{19}$

Hasil penelitian ini menunjukkan pendampingan gizi efektif dalam meningkatkan 
pengetahuan ibu hamil tentang gizi selama kehamilan. Perubahan pengetahuan gizi yang lebih tinggi pada ibu hamil dalam penelitian ini juga dapat disebabkan oleh interval yang pendek antara pretest dan posttest serta hanya dilakukan satu penilaian pasca pendampingan.

\section{Perilaku}

Peran penting nutrisi dalam kehamilan telah diketahui dengan baik dan memiliki implikasi sentral pada kesehatan ibu dan keturunan selanjutnya. Ketika asupan tidak tepat atau tidak memadai, risiko kelahiran prematur dan berat badan lahir rendah meningkat.20,21 Sebaliknya, wanita yang mengalami kenaikan berat badan terlalu banyak selama kehamilan berisiko memiliki bayi yang lebih besar dan retensi berat badan pascapartum. ${ }^{22}$ Oleh karena itu, pendidikan gizi untuk mempromosikan perilaku makan sehat yang berkelanjutan adalah intervensi yang strategis. 23,24

Intervensi yang diberikan dalam penelitian ini secara signifikan berpengaruh terhadap peningkatan asupan asupan energi dan protein pada subjek penelitian. Temuai ini sesuai dengan hasil penelitian Putri (2019) yang menyatakan bahwa pemberian konseling gizi pada ibu hamil berpengaruh secara signifikan terhadap tingkat konsumsi zat gizi energi dan protein. ${ }^{8}$ Hasil penelitian Simbolon (2020) juga menunjukkan adanya perubahan yang signifikan sebelum dan setelah intervensi konseling terhadap asupan energi dan protein pada ibu hamil. ${ }^{25}$

Peningkatan asupan energi dan protein pada subjek penelitian ini masing-masing sebesar 38 persen dan 54 persen. Capaian ini lebih tinggi daripada hasil penelitian Widiyaningsih dkk. (2017) yaitu pemberian konseling gizi dengan media mini flashcard selama 2 bulan memberikan peningkatan terhadap asupan energi dan asupan protein masing-masing sebesar 14,57 persen dan 13,31 persen. ${ }^{26}$ Selanjutnya hasil penelitian Iriandi (2018) menunjukkan adanya peningkatan konsumsi energi dan protein masing-masing sebesar 20 persen dan 16 persen setelah konseling gizi seimbang selama satu kali setiap bulan selama 3 bulan. ${ }^{27}$ Demikian pula dengan hasil penelitian Ananda dkk. (2019) menunjukkan ada pengaruh signifikan antara konseling gizi dengan asupan zat gizi makro.
Setelah diberikan konseling gizi rata-rata asupan energi responden meningkat sebesar 40 persen yaitu dari1.422,2 kkal menjadi 1.991,5 kkal. Asupan protein responden juga meningkat sebesar 53,7 persen yaitu dari 52,3 gram menjadi 80,4 gram. ${ }^{28}$

Meningkatnya asupan energi dan protein dalam penelitian ini diduga berkaitan dengan pengetahuan subjek penelitian. Yuspitra (2019) menyatakan bahwa ada hubungan antara pengetahuan gizi dan asupan zat gizi. Pengetahuan yang dimiliki oleh seorang ibu akan mempengaruhi dalam pengambilan keputusan dan juga akan berpengaruh pada perilakunya, ibu dengan pengetahuan gizi yang baik, akan lebih berpeluang menerapkan praktik gizi yang baik. ${ }^{29} \mathrm{Hal}$ ini sejalan dengan hasil penelitian Yurni dan Sinaga (2017) yang menunjukkan bahwa pendidikan gizi seimbang selama 2 minggu sebanyak 2 kali pertemuan memberikan peningkatan praktik responden terhadap pemilihan menu seimbang sebesar 7,7 persen. ${ }^{13}$ Lebih lanjut Pamilangan (2020) menyatakan bahwa konseling gizi intensif menggunakan media leaflet dapat meningkatkan kualitas diet ibu hamil. ${ }^{30}$

Selain itu, peningkatan asupan zat gizi pada subjek penelitian ini dapat dihubungkan dengan adanya peningkatan pemahaman tentang risiko dan tingkat keparahan kelainan gizi jika praktik gizi yang baik selama kehamilan tidak dijalankan. Demikian pula, wanita yang terpapar informasi nutrisi dapat mengikuti praktik nutrisi yang baik karena bukti penelitian menunjukkan bahwa wanita yang terpapar informasi nutrisi lebih cenderung melakukan praktik diet yang baik. ${ }^{31}$

Perilaku konsumsi suplemen TTD pada subjek penelitian ini juga mengalami peningkatan sebesar $53 \%$ pada kelompok perlakuan dan 35 persen pada kelompok kontrol. Hasil penelitian ini sesuai dengan penelitian Djati dkk. (2017) yaitu ada pengaruh konseling gizi terhadap konsumsi tablet tambah darah pada ibu hamil trimester II dan III, di wilayah Puskesmas II Sumpiuh. ${ }^{32}$

Peningkatan pada kedua kelompok tersebut signifikan secara statistik. Hal ini sesuai dengan pernyataan Piirainen (2006) bahwa konseling diet yang dikombinasikan dengan penyediaan produk makanan selama kehamilan sangat penting dalam memodifikasi makanan dan asupan nutrisi, dengan potensi 
manfaat kesehatan. ${ }^{33}$ Pada kedua kelompok produk suplemen TTD telah disediakan oleh Puskesmas setempat melalui bidan penanggungjawab masing-masing desa sehingga setiap subjek penelitian memiliki akses yang sama terhadap TTD.

Salah satu cara memberikan informasi tentang suplemen TTD adalah dengan melakukan konseling gizi kepada ibu hamil melalui layanan standar ANC. Dengan demikian informasi tentang suplemen TTD juga diperoleh oleh kelompok kontrol melalui bidan sehingga dapat meningkatkan persentase konsumsi TTD pada kedua kelompok. Peningkatan konsumsi suplenen TTD pada kedua kelompok juga diduga karena kegiatan kelas ibu yang diikuti oleh subjek penelitian dari kedua kelompok. Seperti diketahui bahwa pendidikan gizi berpengaruh meningkatkan kepatuhan konsumsi zat besi melalui kelas ibu hamil. ${ }^{34}$

\section{SIMPULAN DAN SARAN}

\section{Simpulan}

Pendampingan gizi bagi ibu hamil oleh nutrisionis melalui konseling gizi empat kali selama satu bulan dapat meningkatkan pengetahuan ibu hamil tentang gizi bayilanak, KIA dan pola asuh. Pendampingan juga meningkatkan asupan energi dan protein ibu hamil. Konsumsi suplemen TTD meningkat pada kedua kelompok. Ini juga membantu meningkatkan asupan makanan selama kehamilan dan meningkatkan kepatuhan terhadap suplemen. Dengan demikian, Kementerian Kesehatan (Depkes) dan organisasi terkait lainnya harus memperluas fokus suplementasi zat besi selama kehamilan kepada audiens pendidikan gizi praktis khusus untuk meningkatkan pengetahuan gizi ibu hamil.

\section{Saran}

Ibu hamil perlu mendapatkan pendampingan gizi secara rutin dan berkesinambungan oleh nutrisionis. Untuk mendukung upaya tersebut diperlukan adanya kebijakan dari stake holder untuk mengembangkan kegiatan kelas ibu dengan pelayanan gizi kehamilan, gizi bayi dan anak. Perlu kajian lanjut tentang durasi dan frekuensi pendampingan yang optimal bagi ibu hamil dan ibu menyusui.

\section{RUJUKAN}

1. De Onis, Mercedes; Branca, Francesco. Childhood stunting: a global perspective. Maternal \& child nutrition, 2016, 12: 12-26.

2. Beal, Ty; Tumilowicz, Alison; Sutrisna, Aang; Izwardy, Doddy; Neufeld, Lynnete M. A review of child stunting determinants in Indonesia. Maternal \& child nutrition, 2018, 14.4: e12617.

3. Purudhon, Claudine; Prinzo, Zita Weise; Briend, Andre; Daelmans, Bernadette M.E.G.; Mason, John B. Proceedings of the WHO, UNICEF, and SCN informal consultation on community-based management of severe malnutrition in children. Food and Nutrition Bulletin, 2006, 27.3_suppl3: S99-S104.

4. Kemenkes RI. Laporan Nasional Riskesdas 2018. Badan Litbangkes, Jakarta : 2019

5. Mikkelsen, Britha. Metode penelitian partisipatoris dan upaya pemberdayaan: Panduan bagi praktisi lapangan. Yayasan Pustaka Obor Indonesia, 2011.

6. Sulaeman, Endang Sutisna; Murti, Bhisma; Waryana, Waryana. Peran Kepemimpinan, Modal Sosial, Akses Informasi serta Petugas dan Fasilitator Kesehatan dalam Pemberdayaan Masyarakat Bidang Kesehatan. Kesmas: Jurnal Kesehatan Masyarakat Nasional (National Public Health Journal), 2015, 9.4: 353-361.

7. Kementerian Perencanaan Dan Pembangunan Nasional/ Badan Perencanaan Dan Pembangunan Nasional. Pedoman pelaksanaan intervensi penurunan stunting terintegrasi di kabupaten/ kota.2018

8. Lemeshow, S. \& David W.H.Jr,. Besar sampel dalam penelitian kesehatan (Terjemahan), Gadjahmada University Press, Yogyakarta; 1997

9. Putri, Si Luh Putu Febriana; Abdi, Lalu Khairul; Sulendri, Ni Ketut Sri; Wirawan, Susilo. Pengaruh pemberian konseling gizi terhadap peningkatan pengetahuan dan 
konsumsi zat gizi ibu hamil anemia di wilayah kerja Puskesmas Pejeruk, Ampenan, Kota Mataram. Jurnal Gizi Prima (Prime Nutrition Journal), 2019, 3.1: 18-27.

10. Puspitasari, Ratri; Supariasa, I Dewa Nyoman; Pudjirahaju, Astutik; Aswin, AAG Anom. Pengaruh konseling gizi seimbang dengan buku saku terhadap perilaku ibu, pola makan serta tingkat konsumsi energi dan protein baduta stunting (Kajian di Desa Sumberngepoh Kecamatan Lawang Kabupaten Malang). Jurnal Pendidikan Kesehatan (e-Journal), 2019, 8.2: 138-150.

11. Diddana, Tona Zema; Kelkay, Gezahegn Niguse; Dola, Amanuel Nana; Sadore, Abinet Arega. Effect of nutrition education based on health belief model on nutritional knowledge and dietary practice of pregnant women in Dessie Town, Northeast Ethiopia: A cluster randomized control trial. Journal of Nutrition and Metabolism, 2018.

12. Zelalem, Ashenafi; Endeshaw, Mulualem; Ayenew, Mamaru; Shiferaw, Solomon; Yirgu, Robel. Effect of nutrition education on pregnancy specific nutrition knowledge and healthy dietary practice among pregnant women in Addis Ababa. Clinics in Mother and Child Health, 2017, 14.3: 265.

13. Daranga, Erniwati; Aminuddin, Aminuddin; Syamsuddi, Saidah. Pengembangan dan evaluasi program konseling gizi intensif dalam peningkatan pengetahuan, ibu hamil terkait intake gizi yang berkualitas. Jurnal Keperawatan Muhammadiyah, 2020, 5.2.

14. Yurni, Adelwais Febriati; Sinaga, Tiurma. Pengaruh pendidikan gizi terhadap pengetahuan dan praktik membawa bekal menu seimbang anak sekolah dasar. Media gizi indonesia, 2017, 12.2: 183-190.

15. Gamelia, Elviera; Kurniawan, Arif; Widiyanto, Agnes Fitria. Pengaruh konseling terhadap peningkatan pengetahuan, sikap, dan perilaku masyarakat tentang kesehatan lingkungan. Kesmas Indonesia, 2015, 7.3: 218-224.

16. Hestuningtyas, Tiara Rosania; Noer, Etika Ratna. Pengaruh konseling gizi terhadap pengetahuan, sikap, praktik ibu dalam pemberian makan anak, dan asupan zat gizi anak stunting usia 1-2 tahun di Kecamatan
Semarang Timur. 2014. PhD Thesis. Diponegoro University.

17.PERSAGI. Konseling Gizi: proses komunikasi, tata laksana, serta aplikasi konseling gizi pada berbagai diet. Penebar Plus. Jakarta, Indonesia; 2013.

18. Ambarwati, Ria; Muis, Siti Fatimah; Susanti, Purwanti. Pengaruh konseling laktasi intensif terhadap pemberian air susu ibu (ASI) eksklusif sampai 3 bulan. Jurnal Gizi Indonesia (The Indonesian Journal of Nutrition), 2013, 2.1.

19. Notoatmodjo, S. Promosi kesehatan dan perilaku kesehatan (Edisi Revi). Rieneka Cipta. Jakarta:2012

20. Hassanzadeh, Akbar; Paknahan, Zamzam; Khoigani, Masoomeh Goodarzi. The relationship between macro-and micronutrients intake and risk of preterm premature rupture of membranes in pregnant women of Isfahan. Advanced biomedical research, 2016, 5 .

21. Imdad, Aamer; Bhutta, Zulfiqar A. Nutritional management of the low birth weight/preterm infant in community settings: a perspective from the developing world. The Journal of pediatrics, 2013, 162.3: S107-S114.

22. Gaillard, Romy; Durmus, Busra; Hofman, Albert; Mackenbach, Johan P; Steegers, Eric A.P.; Jadoe, Vincent W.V. Risk factors and outcomes of maternal obesity and excessive weight gain during pregnancy. Obesity, 2013, 21.5: 1046-1055.

23. Arrish, Jamila; Yeatman, Heather; Williamson, Moira. Midwives and nutrition education during pregnancy: A literature review. Women and Birth, 2014, 27.1: 2-8.

24. Guenther, Patricia M.; Casavale, Kellie O.; Kirkpatrick, Sharon I.; Reedy, Jill; Hiza, Hazel A.B.; Kuczynski, Kevin J.; Kahle, Lisa L.; Krebs-Smith, Susan M. Update of the healthy eating index: HEI-2010. Journal of the Academy of Nutrition and Dietetics, 2013, 113.4: 569-580.

25. Simbolon, Harsita BR; Sry, Winda. Pengaruh penyuluhan gizi terhadap pengetahuan gizi dan pola konsumsi ibu hamil di Desa Bangun Sari Kecamatan 
Tanjung Morawa. Skripsi. Poltekkes Medan Jurusan Gizi. Program Diploma IV. 2019.

26. Endah Widiyaningsih; Joko Susilo; Nurul Huda Syamsiatun. Pengaruh pemberian konseling dengan media leaflet dan mini flashcard terhadap asupan makan dan perubahan z-score BB/U balita gizi kurang di Puskesmas Tempel I. 2017. PhD Thesis. Poltekkes Kemenkes Yogyakarta.

27. Iriandi, M. E. P. B. Pengaruh konseling gizi seimbang terhadap tingkat pengetahuan, sikap, pola konsumsi, tingkat konsumsi energi dan zat gizi serta kadar hemoglobin pada ibu hamil trimester II anemia (Di wilayah kerja Puskesmas Mulyorejo Kota Malang). Skripsi: Politeknik Kesehatan Kemenkes Malang, Malang.2018.

28. Ananda, Meili Dwi; Jumiyati, Jumiyati; Yuliantini, Emy. The influence of nutrition counseling on the knowledge and intake of macro nutrient WUS KEK in region work Puskesmas Sawah Lebar Bengkulu. SANITAS: Jurnal Teknologi dan Seni Kesehatan, 2019, 10.1: 35-45.

29. Yuspitra, Tiara Denisa. Hubungan pengetahuan gizi dan asupan zat gizi (besi, vitamin c, protein) dengan status anemia pada ibu hamil di Desa Nagarejo Kecamatan
Galang, Deli Serdang. KTI. Poltekkes Medan Jurusan Gizi. 2019.

30. Pamilangan, Natalia Rorrong, et al. Pengembangan dan evaluasi program konseling gizi intensif pada ibu hamil dalam meningkatkan kualitas diet. Jurnal Riset Kesehatan Poltekkes Depkes Bandung, 2020, 12.1: 94-99.

31. Ruel, Marie T. Operationalizing dietary diversity: a review of measurement issues and research priorities. The Journal of nutrition, 2003, 133.11: 3911S-3926S.

32. Djati, RR Titis Pitaloka; Sulistyowati, Enik; Hendriyani, Heni. Pengaruh konseling gizi terhadap konsumsi tablet tambah darah dan kadar hb pada ibu hamil trimester II dan III Di Wilayah Puskesmas II Sumpiuh. Jurnal Riset Gizi, 2017, 5.1: 76-85.

33. Piirainen, T., Isolauri, E.; Langstrom, H.; Laitinen, K. Impact of dietary counselling on nutrient intake during pregnancy: a prospective cohort study. British Journal of Nutrition, 2006, 96.6: 1095-1104.

34. Sulastijah, Siti; Sumarni, D. W.; Helmyati, Siti. Pengaruh pendidikan gizi dalam upaya meningkatkan kepatuhan konsumsi zat besi melalui kelas ibu hamil. Jurnal Gizi Klinik Indonesia, 2015, 12.2: 79-87. 
